\title{
СОЦИАЛЬНО-ПСИХОЛОГИЧЕСКИЕ АСПЕКТЫ ПРОФЕССИОНАЛЬНОЙ КУЛЬТУРЫ ИНЖЕНЕРОВ-КОНСТРУКТОРОВ
}

\begin{abstract}
Аннотация. Статья посвящена рассмотрению проблемы исследования социально-психологических аспектов профессиональной культуры инженеров-конструкторов. В работе приводятся результаты исследования социально-психологических аспектов профессиональной культуры инженеров-конструкторов и относящихся $к$ ним ценностных ориентаций и профессиональных установок инженеров-конструкторов промышленных предприятий. В статье описываются также результаты оценки удовлетворенности профрессиональной деятельностью инженеров исследуемых предприятий. Анализ полученных результатов даёт возможность выявить степень готовности инженеров к адаптации в новых социальных условиях инновационной трансформации.

Анализ деятельности инженеров-конструкторов промышленных предприятий выявил, что инженеры-конструкторы демонстрируют неприятие инноваций, имеют смутное представление о содержании инновационных процессов, одновременно выражая позитивное отношение к возможности творчества в работе. Налицо противоречие между ценностями и установками, сложившимися в старых традициях и являющимися тормозом для принятия новых ценностей.

Результаты исследования социально-психологических аспектов профессиональной культуры инженеровконструкторов свидетельствуют о том, что: имеются расхождения между ценностными ориентациями инженеров-конструкторов и их представлениями о необходимости трансрормации элементов профрессиональной культуры в соответствии с инновационными изменениями; профессиональные ценности реализуются лишь в случае выбора инженерами-конструкторами знаний по отдельным блокам как недостающих элементов профессиональной культуры, хотя при этом игнорируются умения и способности; наблюдаются противоречия между ценностными ориентациями и выявленными потребностями инженеров-конструкторов в трансформации своей профессиональной культуры; у большинства инженеров-конструкторов отсутствуют установки на инновации.
\end{abstract}

Ключевые слова: психология, профессиональная культура, социально-психологические аспекты, инженеры-конструкторы, удовлетворенность, деятельность, ценностные ориентации, установки, технология, сознание.

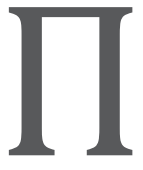
сихологическая проблематика формирования профессиональной культуры специалистов в рамках психологии труда выдвинулась на первый план в связи с изменением условий, средств и характера трудовой деятельности инженеров-конструкторов промышленных предприятий.

На сегодняшний день остро поставлена проблема изучения тех качеств специалистов, которые обычно определяются как психологические. Условия инновационной трансформации потребовали развертывания экспериментально- психологических исследований в области профессиональной деятельности, а также в области формирования профессиональной культуры инженеров-конструкторов.

Высокие темпы изменения технологий, характера и содержания профессионального труда требуют пересмотра соотношения между прошлым, настоящим и будущим в профессиональном сознании специалиста. Заметная эволюция российской ментальности характеризуется трансформацией базовых социальных институтов и новой социальной дифференциацией. 
Изучение социально-психологических аспектов профессиональной культуры инженеров-конструкторов и относящихся к ним ценностных ориентаций и профессиональных установок, даёт возможность выявить степень готовности инженеров к адаптации в новых социальных условиях инновационной трансформации. Исследование ценностных ориентаций и профессиональных установок является приоритетной задачей при анализе профессиональной культуры специалистов (инженеров-конструкторов) и возможностей ее трансформации в соответствии с изменяющимися условиями внешней и внутренней среды предприятия, так как ценностные ориентации и профессиональные установки составляют основу направленности личности, которая составляет одну из основных подструктур динамической функциональной структуры личности.

Теория динамической функциональной структуры личности, разработанная К.К. Платоновым, основывается на признании динамизма и единства личности, взаимосвязи ее общих, особенных и индивидуальных свойств, образующих четыре подструктуры: направленность, опыт, индивидуальные особенности психических процессов и биологически обусловленная подструктура ${ }^{1}$.

Первая подструктура личности объединяет направленность и отношения личности, проявляющиеся как моральные черты. Элементы (черты) личности, входящие в эту подструктуру, не имеют непосредственных врожденных задатков, а отражают индивидуально преломленное групповое общественное сознание. Эта подструктура формируется путем воспитания. Она может быть названа социально обусловленной подструктурой, направленностью личности. Направленность, взятая в качестве целого, в свою очередь, включает в себя такие ее формы: желания, интересы, склонности, мировоззрение. В этих формах направленности личности проявляются и отношения, и моральные качества личности, и различные виды потребностей.

Вторая подструктура личности объединяет знания, навыки, умения и привычки, приобретенные в личном опыте путем обучения, но уже с заметным влиянием и биологически (и даже генетически) обусловленных свойств личности. Эту подструктуру еще называют подготовленностью.

1 Платонов К.К. Структура и развитие личности. М.: Наука, 1986. 370 с.
Третья подструктура личности объединяет индивидуальные особенности отдельных психических процессов, или психических функций, понимаемых как формы психического отражения: памяти, эмоций, ощущений, мышления, восприятия, чувств, воли. Влияние биологически обусловленных особенностей в этой подструктуре видно еще более отчетливо, поскольку формы отражения являются функциями мозга и зависят от его состояния. Эта подструктура, взаимодействуя с остальными, формируется в основном путем упражнения, а изучается преимущественно на индивидуальном психологическом уровне.

Четвертая подструктура личности охватывает свойства темперамента, или типологические свойства личности. Сюда же входят половые и возрастные свойства личности. Кратко эту подструктуру можно характеризовать как биопсихологическую.

Таким образом, в указанные четыре подструктуры могут быть уложены все известные свойства личности. Но изучение профессиональной культуры инженеров-конструкторов, как нам представляется, связано, главным образом, с анализом двух подструктур - подструктуры опыта и подструктуры направленности, а также такого элемента структуры личности как способности, являющегося общим для всех подструктур личности.

Подструктура опыта, включающая в себя такие элементы, как знания, навыки и умения их применять для решения различных задач инженерной деятельности, определяет развитие профессиональных качеств личности инженера, являющихся обязательной предпосылкой и одновременно условием формирования его профессиональной культуры.

Общий объём комплекса теоретических и практических знаний и соответствие знаний в различных областях техники и технологий, экономики и организации производства, требующихся для осуществления квалифицированного инженерного труда, зависит от функций, которые выполняет инженер-конструктор. Чем сложнее инженерные задачи, которые стоят перед специалистом, особенно в условиях инновационной трансформации, тем большим комплексом знаний он должен обладать. Следует отметить, что в структуре личности инженера качества, относящиеся к этой подструктуре, не могут быть компенсированы качествами других подструктур.

Основу подструктуры опыта составляет образовательный уровень инженера, обозначенный 


\section{Профессиональная психология}

нами ранее как «университетское техническое образование», который является важнейшим фактором в формировании мировоззрения инженераконструктора. Во-первых, образование выступает фундаментом профессиональных знаний, определяющих содержание и характер труда инженера; во-вторых, расширяет кругозор, способствует его интеллектуальному совершенствованию, развивает критичность мышления, самостоятельность в оценке общественных явлений, позитивно воздействует на формы и способы социальной ориентации и межличностного общения; в-третьих, воспитывает привычку к постоянному преумножению знаний, чувство неудовлетворенности достигнутым, настойчивость в достижении поставленной цели (характерно, что многими конкретно-социологическими исследованиями установлено, что чем выше образовательный уровень, тем сильнее стремление к дальнейшему приобретению знаний); в-четвертых, дает возможность для приобщения к достижениям культуры, восприятия искусства - эстетическое развитие личности как составная часть ее мировоззренческого развития, по существу, опирается на общий уровень знаний, определяемых главным образом полученным образованием (а также самообразованием); в-пятых, является существенной предпосылкой социальной ответственности инженера-конструктора.

Подструктура направленности, включающая отношения, оценки личности, ее интересы, потребности и убеждения, определяет мировоззренческие ориентации личности инженера. Направленность, аккумулируя неповторимый жизненный опыт личности, отражая своеобразие ее интересов и потребностей, является действенной, активной стороной личности, своеобразным социальным регулятором ее поведения и деятельности. Вне анализа направленности не может быть оценена ни сама личность инженера-конструктора, ни результаты деятельности, ее социально-экономическая эффективность и значимость.

Основу направленности личности составляют ее мотивы. В целом мотивы поведения и деятельности личности определяются такими чертами ее направленности, как потребности, интересы, убеждения, мировоззрение. Однако следует заметить, что мотив выбора инженерной профессии еще не определяет устойчивости интереса к избранной трудовой деятельности. Мотив к инженерной деятельности должен подкрепляться удовлетворени- ем от данной деятельности, только тогда он может превратиться в стойкий интерес.

В этой связи представляется актуальным рассмотрение факторов удовлетворенности профессиональной деятельностью.

Одними из первых отечественных социологов, предложившими свою концепцию удовлетворенности трудом, были А.Г. Здравомыслов и В.А. Ядов. В своей работе они изложили свои взгляды на сущность удовлетворенности трудом, характер ее связей с социологическими категориями, выделили и структурировали определяющие ее факторы, применили математические методы, позволяющие дать количественную оценку ее уровня.

Авторы определяют удовлетворенность трудом как «важнейший элемент общего морального и психологического состояния человека», как «степень реализации установок или требований, которые человек сознательно или не сознательно предъявляет к своей работе»².

Степень удовлетворенности трудом, выявляется в результате сопоставления индивидом своих интересов, связанных с трудовой деятельностью, с возможностями их реализации в конкретных условиях. Исходя из этого, анализируются следующие основные факторы: содержание труда и заработная плата, объективные результаты работы, жизненный и производственный опыт, уровень образования, пол, организация и условия труда и др.

В качестве важнейших факторов, влияющих на удовлетворенность трудом, Р. Штольберг рассматривает уровень образования и квалификацию, а также содержание трудовой деятельности, условия труда, возможность повышения квалификации, понимание общественной значимости труда, знание производственных перспектив. Одни из этих факторов влияют на условия трудовой деятельности, другие - на требования к этим условиям.

Следовательно, на удовлетворенность трудом работников влияют географические, демографические, социально - экономические, социальнопсихологические и психофизиологические группы факторов.

Из всех групп факторов следует выделить социально-экономические, социально-психологические и психофизиологические группы, влияющие

\footnotetext{
Ядов В.А., Кисель А.А. Удовлетворенность работой: анализ эмпирических обобщений и попытка их теоретического обоснования // Социологические исследования. 1974. № 1. C. $78-87$.
} 
на удовлетворенность трудом. В составе каждой группы могут быть выделены общие и специфические факторы, внутренние и внешние, измеряемые и не измеряемые, регулируемые и не регулируемые. При анализе факторов удовлетворенности мы опирались на принципы классификации мотивов с точки зрения системного подхода, предложенного В.Д. Шадриковым ${ }^{3}$.

Составной частью изучения проблем удовлетворенности трудом является изучение отношения к работе и восприятия собственного труда инженерами-конструкторами различных промышленных предприятий. Как работники воспринимают свою работу, отношение с руководством, насколько считают свой труд должным образом вознагражденным - все эти аспекты отношения к работе дают важную информацию об уровне удовлетворенности трудом инженеров-конструкторов. Для получения информации нами было проведено исследование реальной ситуации на промышленных предприятиях Омской области (ЗАО «Омский завод «Автоматика», ОАО «ОМашКБ», ОАО «ОМКБ»), на промышленном предприятии Тюменской области (000 «Тобольск-Нефтехим»), а также на предприятии ОАО «Сургутнефтегаз», расположенном в Ханты-Мансийском автономном округе (Югре).

Главной целью исследования является изучение степени удовлетворенности трудом инженеров-конструкторов предприятий и факторов, влияющих и способствующих ее повышению. В выборку попали 665 человек: инженеры-конструкторы промышленных предприятий Омской области (всего 450 человек), инженеры-конструкторы промышленных предприятий Тюменской области (всего 115 человек), инженеры-конструкторы промышленных предприятий Ханты-Мансийского автономного округа (Югры) (всего 100 человек). Все респонденты внутри этих групп распределялись по стажу работы и возрастным характеристикам. Большая часть опрошенных работники со стажем более 5 лет, чуть меньше половины участников анкетирования - работники со стажем от 1 до 5 лет. Средний возраст респондентов - 41, 94+9, 584 лет.

По результатам исследования можно определить, какие факторы действуют на удовлетворенность трудом в большей степени; изучить

\footnotetext{
3 Шадриков В.Д. Деятельность и способности. М.: Издат. корпорация «Логос», 2004. 320 с.
}

восприятие работниками условий своего труда, трудового вознаграждения; исследовать причины низкой удовлетворенность трудом; соотнести полученные данные с данными об уровне образования, квалификации, должности; провести статистическое обобщение и интерпретирование данных.

В качестве метода сбора информации был выбран анкетный опрос, как оперативный и надежный метод получения интересующих нас данных. Анкета представляется достаточно эффективным исследовательским инструментом. В анкету были включены вопросы, по которым можно оценить степень удовлетворенности трудом работников.

Результаты оценки удовлетворенности своей работой участников анкетирования приведены в следующей таблице:

Таблица 1

Результаты оценки удовлетворенности своей работой, по мнению опрошенных, в \%

\begin{tabular}{|c|c|c|c|c|c|}
\hline 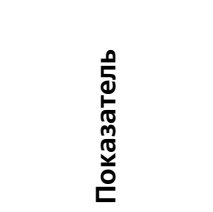 & 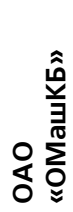 & 웡 & 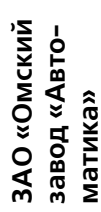 & 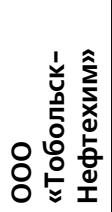 & 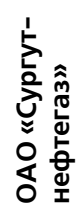 \\
\hline $\begin{array}{l}\text { Вполне удов- } \\
\text { летворены }\end{array}$ & 54 & 55 & 63 & 43 & 71 \\
\hline $\begin{array}{l}\text { Не вполне } \\
\text { удовлетворены }\end{array}$ & 34 & 36 & 30 & 40 & 22 \\
\hline $\begin{array}{l}\text { Совсем не удов- } \\
\text { летворены }\end{array}$ & 4 & 5 & 1 & 10 & 6 \\
\hline Затрудняюсь & 8 & 4 & 6 & 7 & 1 \\
\hline
\end{tabular}

Самый высокий показатель удовлетворенности на предприятии ОАО «Сургутнефтегаз»$71 \%$ респондентов, самый низкий показатель удовлетворенности работой на предприятии 000 «Тобольск-Нефтехим» - 43 \%. На этом же предприятии наблюдается низкий уровень профессиональной культуры. Исследование показало, что на предприятиях с ростом уровня профессиональной культуры наблюдается рост удовлетворенности трудом инженеров-конструкторов.

Одним из важных показателей удовлетворенности трудом в организации является соответствие трудового поста знаниям и опыту работников. Предпочтения по этому поводу респондентов представлены в таблице 2.

Соответствие трудового поста знаниям и опыту работников на предприятии ОАО «Сургутнефтегаз» составляет 73 \%, что свидетельствует 
о высоком уровне профессиональной культуры и удовлетворенности трудом. На предприятии 000 «Тобольск-Нефтехим» соответствие составляет лишь $49 \%$.

Таблица 2

Соответствие трудового поста знаниям и опыту работников, по мнению опрошенных, \%

\begin{tabular}{|c|c|c|c|c|c|}
\hline 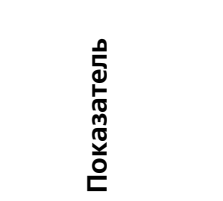 & 垱 & ○铈 & 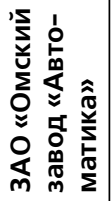 & 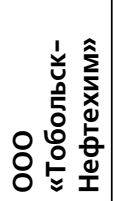 & 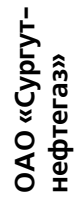 \\
\hline $\begin{array}{l}\text { Об этом не за- } \\
\text { думывался }\end{array}$ & 13 & 10 & 12 & 15 & 11 \\
\hline $\begin{array}{l}\text { Соответствует } \\
\text { полностью }\end{array}$ & 55 & 60 & 72 & 49 & 73 \\
\hline Не соответствует & 5 & 3 & 0 & 6 & 0 \\
\hline $\begin{array}{l}\text { Скорее соответ- } \\
\text { ствует, чем нет }\end{array}$ & 22 & 20 & 15 & 26 & 12 \\
\hline $\begin{array}{l}\text { Скорее не соот- } \\
\text { ветствует, чем } \\
\text { соответствует }\end{array}$ & 5 & 7 & 1 & 4 & 4 \\
\hline
\end{tabular}

Важный показатель удовлетворенности трудом - взаимоотношения в коллективе. Мнение респондентов по вопросу, удовлетворены ли они взаимоотношениями в коллективе, приведены в таблице 3.

Таблица 3

Удовлетворенность взаимоотношениями в коллективе, по мнению опрошенных, в \%

\begin{tabular}{|c|c|c|c|c|c|}
\hline 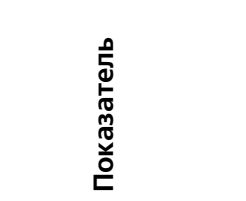 & 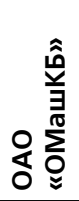 & 웅 & 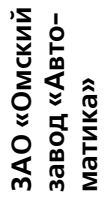 & 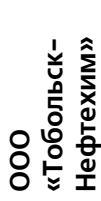 & 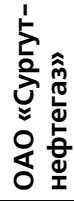 \\
\hline Да, вполне & 32 & 35 & 45 & 38 & 44 \\
\hline Скорее да, чем нет & 38 & 45 & 40 & 32 & 39 \\
\hline Скорее нет, чем да & 11 & 15 & 12 & 15 & 11 \\
\hline Не удовлетворен & 12 & 4 & 3 & 13 & 4 \\
\hline Затрудняюсь & 7 & 1 & 0 & 2 & 2 \\
\hline
\end{tabular}

По данным таблицы можно сделать вывод о том, что самый высокий уровень удовлетворенности взаимоотношениями в коллективе - на предприятии ЗАО Омский завод «Автоматика»$45 \%$, самый низкий уровень на предприятии ОАО «ОМашКБ» - 32 \%.

На открытый вопрос анкеты откликнулись около 50\% респондентов, которые предложили условия, способствующие успешной работе:

- повышение заработной платы;
- закупка нового оборудования;

- возможность постоянного повышения квалификации.

Условия, которые мешают успешной работе, это: - низкая заработная плата;

- $\quad$ недостаточное количество заказов.

По результатам исследования следует сделать вывод, что на обследованных предприятиях достаточно высокая удовлетворенность трудом инженеров-конструкторов, что связано с возможностью постоянного повышения квалификации на предприятиях, высокой степенью адаптации работников (стаж работы большинства опрошенных более 5 лет) и возможностью творческой реализации своих возможностей. Однако, основной проблемой, снижающей удовлетворенность трудом респондентов, является низкий уровень заработной платы для данной категории работников на обследованных предприятиях машиностроительной отрасли.

Результаты проведенного анкетирования позволяют эмпирически подтвердить наличие взаимосвязи между длительностью стажа работы инженера-конструктора на предприятии и степенью его удовлетворенности осуществляемой деятельностью.

Специфика личности инженера-конструктора и обуславливается, прежде всего, наличием органической взаимосвязи и тесного единства опыта и направленности. С одной стороны, различные знания, умения, навыки, которыми владеет инженер, определяют содержание инженерной деятельности, ее организацию и эффективность, но с другой стороны, своеобразие этой деятельности, ее характер, стиль, цель, смысл и значимость результатов будут, несомненно, определять именно направленность личности инженера-конструктора (интересы, убеждения, ценностные ориентации, мировоззрение).

Профессиональная направленность имеет огромное значение для владения инженерным трудом. В аспекте личной значимости профессии инженера-конструктора добавим лишь такой общий для всех профессий момент, как престижность, важность которой показана в ряде работ (Е.А. Климов, Е.П. Ильин).

“Профессионально компетентного инженера-конструктора отличает зрелое мировоззрение, характеризующееся чертами осознанности интересов и идеалов, правовых и нравственных норм и принципов, социальных приоритетов и гуманистических ценностей. Превращаясь в убеждения 
личности и соединяясь с ее волевыми качествами, именно они определяют выбор стиля поведения и деятельности, ответственное отношение специалиста к окружающему миру, к обществу, к труду, к людям, к самому себе", - утверждает Л.Д. Томалинцева. И с ней нужно согласиться, поскольку нравственные, моральные качества личности, входящие в подструктуру направленности, во многом определяют успешность деятельности инженераконструктора, a, следовательно, играют большую роль в формировании профессиональной культуры инженеров-конструкторов.

Так как нормы морали заключают в себе общественную необходимость, то признаком нравственности личности следует считать меру освоения и принятия моральной необходимости как лично значимой. Нравственность личности может быть представлена как система ее ценностных отношений к общественно значимым нормам. Из этого, в частности, следует, что основу успешной деятельности инженера-конструктора составляет его умение и желание в своей повседневной деятельности принимать решения, опираясь на предпочтения, учитывающие подчиненность их основным нравственным ценностям общества и коллектива. По нашему убеждению, на эту способность инженера-конструктора оказывает определяющее влияние мировоззрение самого работника, его собственные взгляды на то, какими должны быть трудовые отношения.

Несомненно, что во многом профессиональная культура инженера-конструктора и эффективность его деятельности определяются знанием себя, своих способностей и возможностей. Приобретаемые знания, умения и навыки зависят не только от внешней деятельности, но также и от субъективных особенностей личности инженераконструктора и прежде всего - от способностей, которые являются общим элементом для всех четырех подструктур личности.

Специальное образование, профессиональные навыки и умения, т.е. профессиональный опыт, определяют меру развития способностей, но сами способности к наличию этих знаний, умений, навыков не сводятся. По отношению к ним способности выступают как возможности по овладению ими, т.е. способности обнаруживаются в динамике приобретения опыта (умений, навыков), в том, насколько при прочих равных условиях быстро, глубоко, легко и прочно осуществляется процесс овладения знаниями и умениями, существенно важными для данной деятельности.
Мера развития и совершенствования профессиональных способностей личности выражается ее квалификацией. Квалификация является ядром профессиональной культуры на ее технологическом уровне, и по своему содержанию объединяет вышеперечисленные элементы профессиональной культуры, - такие как специальное образование, навыки и умения. Можно согласиться с тем, что в зависимости от того, насколько высока степень квалификации, настолько успешнее личность материализует свои сущностные силы, эффективными будут ее трудовые усилия. Но необходимо учитывать, что профессиональная культура не совсем тождественна профессиональной деятельности личности, она характеризует формы специализированной деятельности с точки зрения реализации в ней способностей, дарований, потребностей личности.

Степень реализации специальных способностей и возможность занятия в связи с этим определенной должности зависит в основном от таких обстоятельств, как полученное образование и, данный от природы, уровень мышления, для развития которого образование является определенной базой.

Однако достичь высокого уровня вышеназванных способностей возможно, по нашему мнению, при наличии у инженера-конструктора эффективной системы самоуправления. С помощью самоконтроля человек проверяет правильность своих действий, поступков и адекватность различных форм поведения в соответствии со своими правами и обязанностями перед другими людьми. Процесс общения людей друг с другом, их поведение в обществе невозможны без актуализации самоконтроля, с помощью которого человек осознанно контролирует свои отношения, свое поведение в соответствии с усвоенной им системой социальных эталонов. Роль этих эталонов выполняют социальные нормы (нравственные, эстетические, правовые) или образцы поведения, указывающие на определенную направленность общественного поведения людей.

Несформированность самоконтроля, неумение им пользоваться или нежелание к нему обратиться - все это неминуемо ведет к нежелательным последствиям (профессиональные неудачи, асоциальное поведение, распад личности). Чем выше уровень профессиональной культуры инженера-конструктора, тем более прочными и разнообразными приемами самоконтроля он владеет. Так Г.С. Никифоров обоснованно отмечает, что само- 
контроль пронизывает все психические явления, присущие человеку и тесно связан с самооценкой и уверенностью в себе. Люди с хорошо выраженным самоконтролем обнаруживают и более адекватную самооценку. Напротив, при недостаточно сформированном самоконтроле наблюдается явное преобладание неадекватной самооценки, причем чаще всего в сторону завышения. Те, кому присущи адекватная самооценка и высокоразвитый самоконтроль, обычно обнаруживают и более выраженное развитие таких качеств, как чувство долга, дисциплинированность, добросовестность, организованность и ответственность ${ }^{4}$.

Несомненно, что управлять своим поведением и подчинять его требованиям, предъявляемым социальным окружением, можно только с помощью постоянного самоконтроля своих намерений. Самоконтроль - это центр нравственной сферы инженера-конструктора, через который преломляются моральные качества личности, которые, бесспорно, являются основополагающими в личности любого успешного инженера-конструктора, а, следовательно, их также можно отнести к структурной составляющей его профессиональной культуры.

В соответствии с задачами исследования, необходимо рассмотреть профессиональную культуру инженеров-конструкторов как систему ценностей определенной профессиональной группы, ценностей, взятых в профессиональном аспекте.

Результаты проведенного исследования, включающего опрос по ценностным ориентациям инженеров-конструкторов, позволяют выявить особенности их профессиональной культуры. В опросе приняли участие 665 человек: инженеры-конструкторы промышленных предприятий Омской области (всего 450 человек), инженерыконструкторы промышленных предприятий Тюменской области (всего 115 человек), инженеры-конструкторы промышленных предприятий Ханты-Мансийского автономного округа (Югры) (всего 100 человек). В качестве основного метода исследования использовалось анкетирование и интервьюирование.

Для проведения исследования нами использовались профессиональные, гуманистические и социальные системы ценностей. Профессиональная система ценностей объединяет ценности профессиональной группы, предопределяющие цели

\footnotetext{
4 Никифоров Г.С. Самоконтроль человека. Л.: Наука, 1989.
} $150 \mathrm{c.}$ деятельности и профессиональную сущность личности. Социальная система ценностей предполагает рассмотрение ценностных ориентаций инженера-конструктора, находящегося в определенной социотехнической и социокультурной среде, что позволяет рассматривать ценностные суждения, необходимые для сохранения и повышения эффективности взаимодействия человека и техники. Это выражается прежде всего в признании необходимости социальной и экологической оценок техники, в осознании степени ответственности инженера за результаты своей деятельности, как важнейшие для последующего развития научнотехнического прогресса. А также в рамках этой системы необходимо рассмотреть те ценности, которые определяют процесс формирования личности в определенной социокультурной среде. Гуманистическая система предполагает рассмотрение ценностных суждений, необходимых для создания условий безопасности и профессионального развития себя и других работников.

В рамках проведения опроса, связанного с ценностными ориентациями инженеров-конструкторов, им было предложено ответить на вопрос: «Какие ценности являются для Вас приоритетными в Вашей профессиональной деятельности?». Далее следовал список наиболее существенных профессиональных ценностей (ценностей профессионального роста, самореализации, самосовершенствования, принесения пользы обществу, материального вознаграждения и т.д.). В результате опроса были получены данные о суждениях инженеров-конструкторов промышленных предприятий указанных ранее регионов, отражающие их ценностные ориентации по каждому из вышесказанных блоков. Полученные данные представлены в таблице 4. При этом справа расположенные ответы, явно относящиеся к данной системе ценностей, слева - противоположной направленности.

Полученные результаты наглядно демонстрируют, что инженеры-конструкторы имеют достаточно развитые социально ориентированные профессиональные ценности, потребность в сопричастности, товарищеской взаимопомощи, стремление к общению.

На наш взгляд, это можно объяснить достаточно длительным периодом коллективизма на отечественных промышленных предприятиях, когда мотивом совместной деятельности является группа и коллектив в целом. При этом участники совместного труда взаимно дополняют друг друга, 
достигая высокого уровня сплоченности, показателем которой является ценностно-ориентационное единство. Следует также отметить, что средний возраст респондентов - 41, 94+9, 584 лет, что говорит об их возможной принадлежности к бывшей советской модели управления предприятиями. Возможно, именно с этим связана ориентация инженеров-конструкторов на социально-ориентированные профессиональные ценности: «Возможность влиять на результаты своего труда» $(58,2 \%)$; «Быть полезным обществу» $(54,3 \%) ;$ «Общение с людьми» $(42,8 \%)$.

Таблица 4

Профессиональные ценности, ответы в \%

\begin{tabular}{|l|l|}
\hline Социально ориентированные & Личностно ориентированные \\
\hline $\begin{array}{l}\text { Возможность влиять } \\
\text { на результаты своего труда } \\
(58,2)\end{array}$ & $\begin{array}{l}\text { Соответствие задач } \\
\text { своим способностям } \\
(32,1)\end{array}$ \\
\hline $\begin{array}{l}\text { Быть полезным обществу } \\
\text { коллективу) }\end{array}$ & $\begin{array}{l}\text { Величина заработной платы } \\
(54,3)\end{array}$ \\
\hline $\begin{array}{l}\text { Возможность участвовать } \\
\text { в процессе принятия решений } \\
(18,3)\end{array}$ & $\begin{array}{l}\text { Возможность оказывать } \\
\text { влияние на людей } \\
(2,5)\end{array}$ \\
\hline $\begin{array}{l}\text { Возможность общения } \\
\text { с людьми } \\
(42,8)\end{array}$ & $\begin{array}{l}\text { Возможность проявлять } \\
\text { инициативу }\end{array}$ \\
\hline
\end{tabular}

Среди личностно ориентированных ценностей наибольшей вес имеют потребности в самореализации и самоактуализации. При этом материальные потребности и потребности во влиянии (пункт «возможность оказывать влияние на людей») у данной группы инженеров-конструкторов оказались развиты незначительно.

С одной стороны, можно говорить о наличии профессиональных ценностей, связанных с профессиональными достижениями («возможность влиять на результаты своего труда», «возможность участвовать в процессе принятия решений») и профессиональным общением («быть полезным обществу, коллективу», «возможность общения с людьми»), что в полной мере коррелируется с потребностью в профессиональном развитии.

С другой стороны, наблюдается несовпадение профессиональных ценностей и потребностей формирования соответствующих элементов профессиональной культуры. Казалось бы, профессиональные ценности должны вызывать потребности в формировании ряда элементов профессиональной культуры. Однако в основном такие потребности имеются лишь в отношении знаний новой техники и технологий, основ психологии, эргономики, знание установленных норм и стандартов и др. Что касается различных умений, составляющих необходимое звено ключевых компетенций инженеров-конструкторов, то в них респонденты потребностей не испытывают.

Анализ результатов исследования гуманистических ценностей показывают, что наблюдается трансформация прежних ценностей. На промышленных предприятиях на сегодняшний день происходит отказ от прежних ценностей и принятие новых, в связи с чем наблюдается противоречивая картина полученных результатов. Большая часть опрошенных инженеров продолжает считать, что работник предприятия должен только лишь стараться качественно и в срок выполнять поручения руководства, не проявляя инициативы и не участвуя в процессе принятия решений, другие же отдают приоритет творческому подходу, считая, что каждый работник может принимать участие в инновационном поиске новых креативных идей и решений и создавать тем самым условия для удовлетворения своих потребностей в самореализации. Результаты анализа гуманистических ценностей представлены в таблице 5.

Таблица 5

Гуманистические ценности

\begin{tabular}{|c|l|c|}
\hline $\begin{array}{c}\text { № } \\
\mathbf{n} / \mathbf{n}\end{array}$ & \multicolumn{1}{|c|}{ Наименование ценности } & $\begin{array}{c}\text { Ответы, } \\
\text { в \% }\end{array}$ \\
\hline 1. & $\begin{array}{l}\text { Отношение к себе и к другим работникам как } \\
\text { к основному ресурсу предприятия }\end{array}$ & 79,5 \\
\hline 2. & $\begin{array}{l}\text { Убеждение, что необходимо проявлять } \\
\text { инициативу и искать инновационные пути } \\
\text { решения производственных задач }\end{array}$ & 53,5 \\
\hline 3. & $\begin{array}{l}\text { Убеждение, что необходимо поддерживать } \\
\text { инициативу других работников }\end{array}$ & 57,9 \\
\hline 4. & $\begin{array}{l}\text { Убеждение, что руководство предприятия } \\
\text { должно поощрять творческий поиск работ- } \\
\text { ника к решению инновационных задач }\end{array}$ & 63,7 \\
\hline 5. & $\begin{array}{l}\text { Работник должен быть безотказен в выпол- } \\
\text { нении любого поручения и уметь выполнить } \\
\text { (даже не интересную) работу на уровне вы- } \\
\text { соких стандартов }\end{array}$ & 27,6 \\
\hline
\end{tabular}

Результаты проведенного опроса свидетельствуют о возрастании роли гуманистических ценностей. Работники в полной мере осознают ценность и значимость своего труда. Особенно интересен тот факт, что большинство опрошенных инженеров-конструкторов видят себя в роли инноваторов и стремятся поддерживать эти инициативы у других работников. Тем не менее, достаточно большой процент респондентов $(27,6)$ 


\section{Профессиональная психология}

поддерживают отношение к работнику как к безотказному, послушному исполнителю, что говорит о недооценке человеческого фактора и необходимости трансформации элементов профессиональной культуры в соответствии с инновационными изменениями. Хотя, если исходить из того, что достаточно высок процент тех, кто указал на необходимость отношения к себе и другим работникам со стороны руководства как к основному ресурсу предприятия, должны быть востребованы такие качества, входящие в структуру профессиональной культуры, как «умение проявлять сопереживание» «умение согласовывать свои интересы с интересами других людей» и др. Однако результаты проведенных ранее исследований свидетельствуют о том, что указанные качества оказались не востребованы инженерами-конструкторами.

Исследование социальных ценностей имеет важное значение для выявления отношения инженеров-конструкторов к значимости формирования отдельных элементов их профессиональной культуры. В связи с этим приобретает важность рассмотрение ценностей инженеров-конструкторов, находящихся одновременно в определенной социотехнической и социокультурной среде, в связи с чем особую значимость приобретают такие составляющие профессиональной культуры, как профессиональная инженерная компетентность, предполагающая понимание социокультурных смыслов техники и инженерной деятельности и социально-культурная включенность инженера-конструктора (профессиональная культурная компетентность)», которая включает сочетание теоретических знаний и практических навыков, регламентируемых установленными нормами и стандартами, профессиональную мобильность, позволяющую быстро переучиваться, приобретать новые знания и ориентироваться в нестандартных ситуациях. Результаты исследования социальных ценностей инженеров-конструкторов представлены в таблице 6.

В рамках исследования социальных ценностей особое внимание уделялось приобщению инженеров-конструкторов к инновационной и творческой деятельности, стремлению к овладению навыками эффективного общения, усвоению коллективных ценностей и др. Однако, как следует из таблицы 6, инженеры-конструкторы в большей степени ориентированы на повышение количественных и качественных результатов своего труда (более 70\% опрошенных), чем на приобщение к творческой деятельности. Потребности в росте и повышении своей профессиональной и социальной эффективности присутствуют у большинства респондентов, но тем не менее многие инженеры-конструкторы (более 80\% опрошенных) не считают необходимым развивать свои коммуникативные навыки и приобретать знания по основам психологии и этики общения. Многие респонденты также не оценивают значимости и приоритетности тех ценностей и норм, которые приняты на предприятии, вследствие слабо развитой корпоративной культуры.

таблица 6

Социальные ценности, ответы в \%

\begin{tabular}{|c|c|}
\hline $\begin{array}{l}\text { Ценности социотехнической } \\
\text { системы }\end{array}$ & $\begin{array}{c}\text { Социокультурные } \\
\text { ценности }\end{array}$ \\
\hline $\begin{array}{c}\text { Поиск новых подходов в реше- } \\
\text { нии профессиональных задач } \\
(42,7)\end{array}$ & $\begin{array}{c}\text { Приобщение к корпоратив- } \\
\text { ной культуре предприятия } \\
\text { (32) }\end{array}$ \\
\hline $\begin{array}{c}\text { Приобщение к творческой } \\
\text { деятельности (59) }\end{array}$ & $\begin{array}{c}\text { Повышение эффективности } \\
\text { взаимодействия с коллегами } \\
(63,3)\end{array}$ \\
\hline $\begin{array}{c}\text { Понимание тенденций и ос- } \\
\text { новных направлений развития } \\
\text { науки и техники }(32,3)\end{array}$ & $\begin{array}{c}\text { Развитие коммуникативных } \\
\text { навыков }(17,2)\end{array}$ \\
\hline $\begin{array}{c}\text { Рост профессиональной мо- } \\
\text { бильности }(32,8)\end{array}$ & $\begin{array}{c}\text { Знание психологии и этики } \\
\text { общения }(12,3)\end{array}$ \\
\hline $\begin{array}{c}\text { Повышение количественных } \\
\text { и качественных результатов } \\
\text { своего труда }(77,5)\end{array}$ & $\begin{array}{c}\text { Владение навыками управ- } \\
\text { ления профессиональной } \\
\text { группой или коллективом } \\
(34,5)\end{array}$ \\
\hline
\end{tabular}

Указанное противоречие обусловлено, по нашему мнению, недостаточно адекватными представлениями об эталонной и своей реальной профессиональной культуре, и как следствие недостаточно развитые потребности в формировании определенных ее составляющих. С другой стороны, возможны погрешности в определении ценностных ориентаций по причине выбора «социально одобряемых ценностей».

Результаты опроса говорят о неразвитости социокультурной системы ценностей инженеров-конструкторов промышленных предприятий. Полученные результаты опросов позволяют утверждать, что у большинства инженеров выявлена единая характеристика - игнорирование проблем социально-культурной среды, в которой разворачивается их инженерная деятельность.

В качестве особенностей ценностного сознания инженеров-конструкторов промышленных предприятий в этом исследовании необходимо отметить достаточно высокий процент выбора таких ценностей, как «Отношение к себе и к другим ра- 
ботникам как к основному ресурсу предприятия» $(79,5)$, «Повышение количественных и качественных результатов своего труда» $(77,5)$ и «Возможность влиять на результаты своего труда» $(58,2 \%)$.

Помимо исследования ценностных ориентаций инженеров-конструкторов в рамках изучения социально-психологических аспектов профессиональной культуры, необходимо, как было сказано ранее проанализировать механизмы регуляции профессиональной деятельности инженера-конструктора, определяющие его поведение и поступки. Представления о механизмах регуляции были развиты в психологической теории установки, определяемой как готовность, предрасположенность субъекта действовать определенным образом.

Профессиональные установки проявляются в условиях реальной профессиональной деятельности инженера и обеспечивают его самоорганизацию. Находясь в условиях определенной социотехнической системы, инженер-конструктор моделирует свое профессиональное поведение исходя из существующих в его сознании профессиональных установок.

В этой связи их исследование представляется чрезвычайно важным, поскольку знание их особенностей обеспечивает устойчивый и целенаправленный характер протекания деятельности, служит средством её стабилизации и развития в заданном направлении. Вместе с тем, это имеет и негативную сторону, поскольку установка может стать фактором сопротивления инновационным изменениям.

Рассматривая установки как предрасположенность субъекта действовать определенным образом, следует отметить, что в деятельности инженера-конструктора могут быть такие установки, которые являются частью профессии и необходимым признаком профессионализма.

Изучение деятельности инженеров-конструкторов промышленных предприятий указанных ранее регионов (на основании вторичного анализа материалов исследований) позволило сформулировать основные характеристики инженерной деятельности:

- $\quad$ готовность к техническому творчеству;

- способность осуществлять инженерную деятельность, что предполагает сочетание теоретических знаний и практической подготовленности субъекта труда;

- $\quad$ способность к поиску новых креативных подходов в решении профессиональных задач;
- устойчивое, осознанное отношение к своей профессии, стремление к постоянному личностному и профессиональному совершенствованию;

- коммуникационная готовность (знание психологии и этики общения, владение навыками управления профессиональной группой или коллективом);

- владение методами технико-экономического анализа производства с целью его рационализации и оптимизации;

- понимание тенденций и основных направлений развития науки и техники ${ }^{5}$.

Среди перечисленных установок, наиболее типичной установкой в среде инженеров-конструкторов является «готовность к техническому творчеству». Она проявляется в том, что в процессе своей практической деятельности инженер-конструктор обязан находить элементы нового даже в решении таких задач, которые принято рассматривать как традиционные. Для этого он должен перерабатывать огромное количество информации и транслировать умения творчески использовать научные знания, проектировать и конструировать различные объекты, так как инженерная деятельность является промежуточной между научной и практической для создания конкретных технических объектов, имеющих более прогрессивную структуру и функционирование. Инженер в процессе своей профессиональной деятельности решающим образом влияет на развитие технического базиса общества, его экономики и управления. Вместе с тем сама по себе деятельность инженера является гуманистической, поскольку в результате этой деятельности улучшаются условия труда, повышается качество выпускаемой продукции. Сущность инженерного труда, как было отмечено ранее, определяется такими признаками, как техническая направленность, практический характер целей и задач, высокая степень творчества, взаимосвязь с наукой, применение научных знаний.

Профессиональное содержание труда инженера-конструктора выражается в конкретных производственных функциях, определяемых в результате разделения и кооперации труда внутри производственных коллективов. Выделяют следующие инженерные функции в технических службах предприятий:

Багдасарьян Н.Г. Профессиональная культура инженера: механизмы освоения. М.: Изд-во МГТУ им. Н.Э. Баумана, 1998. 150 c. 


\section{Профессиональная психология}

- инженерное обслуживание текущего производства, включая инженерную проработку решений руководства, размещение производственного процесса в пространстве, организацию труда рабочих, контроль качества продукции и эксплуатации оборудования;

- $\quad$ разработку, организацию и осуществление повышения качества продукции;

- $\quad$ техническую подготовку производства новых видов продукции (конструкторскую и технологическую);

- решение задач, носящих общетеоретическое значение;

- стратегическое прогнозирование развития производства;

- стратегическое прогнозирование будущей продукции.

В соответствии с данными функциями инженерной деятельности можно выделить общие и специфические установки, а также актуальные востребованные в данный момент, и проективные которые должны быть актуальны в будущем.

Тогда под общими установками следует понимать такие, которые характеризуют готовность к выполнению профессиональных инженерных функций в рамках рационалистических служебных традиций, например, «верность традициям», «принципиальность», «честность». Специфические же установки связаны с готовностью осуществлять виды деятельности по таким отдельным направлениям, как «осуществлять наиболее продуктивную деятельность», «технологизировать трудовой процесс», «строить эффективные коммуникации» и др.

Основываясь на приведенных выше материалах психологических исследований, можно сделать вывод, что для большинства инженеров-конструкторов типичными являются установки, связанные с готовностью следовать инструкциями и служебными традициями.

Вместе с тем, современное промышленное предприятие должно ответить на креативный вызов общества собственной креативностью.

В организации и осуществлении инновационной деятельности значительную роль играет руководство предприятия как субъект отношений по управлению этой деятельностью. Достаточно указать только часть таких функций, которые должны выполнять инженеры-конструкторы для развития инноваций, чтобы понять значимость установок к инновациям и творчеству. Это - повышение эффективности деятельности современного промышленного предприятия за счет обеспечения создания высокотехнологичной и конкурентоспособной продукции; разработка новых инновационных предметов и средств труда, способствующих повышению эффективности труда работников, занятых в других отраслях; привлечение инвестиций на предприятие для финансирования инновационных программ и проектов; привлечение на предприятие государственных заказов на закупку продукции; развитие научно-технического прогресса в целом и т.д.

В связи с этим, есть основание считать, что будущее российской промышленности определяется в первую очередь инновационными установками и деятельностью инженеров крупных промышленных предприятий, особенно инженеров-конструкторов, оказывающих целенаправленное воздействие на ход трансформационного процесса. Это определяет актуальность исследования наличия данных установок у инженеров-конструкторов промышленных предприятий России.

В рамках проведенного исследования ценностных ориентаций инженеров-конструкторов, о результатах которого было сказано выше, был проведен также опрос, направленный на выявление профессиональных установок на инновации и творчество. В данном опросе также приняли участие 665 человек: инженеры-конструкторы промышленных предприятий Омской области (всего 450 человек), инженеры-конструкторы промышленных предприятий Тюменской области (всего 115 человек), инженеры-конструкторы промышленных предприятий Ханты-Мансийского автономного округа (Югры) (всего 100 человек).

Результаты проведенного исследования свидетельствуют, что в основном инженеры-конструкторы осознают необходимость внедрения инноваций в свою деятельность. Хотя, судя по ответам, демонстрируют слабую готовность к исследованиям и инновациям в своей деятельности. Инженеры-конструкторы имеют весьма смутное представление о сущности инноваций, содержании инновационных процессов и инновационной деятельности. Распределение ответов на вопрос «Необходимы ли инновации в инженерной деятельности?» следующие: «да, нужны» - 15,9\%; «скорее да, чем нет» - 35,5\%; «скорее нет, чем да» - 33,3\%; «нет»-9,7\%, затруднились ответить 5,6\% опрошенных.

Однако инженеры-конструкторы продемонстрировали весьма позитивное отношение 
к возможности творчества в работе. Распределение ответов на вопрос: «Полагаете ли Вы, что инженерам-конструкторам должно быть присуще творчество в работе?» оказалось следующее: $52,6 \%$ опрошенных в этом полностью уверены, 35,9\% выбрали ответ «скорее да, чем нет», 7,8\% выбрали ответ «скорее нет, чем да» и лишь 1,8\% считают, что «нет». При этом только незначительная часть респондентов затруднилась в выборе ответа (1,9\%). Примерно такое же распределение наблюдается при ответе на вопрос: «Полагаете ли Вы, что творчество - удел одаренных?». Это можно прокомментировать следующим образом. В основном подтверждается убеждение, что инженерам-конструкторам необходимо творчество в работе и преобладает уверенность, что оно присутствует. Тогда возникает вопрос, почему только $15,9 \%$ опрошенных поддерживают инновации, а $35,5 \%$, хотя и поддерживают, но, в сущности, сомневаются в своем выборе.

Указанное противоречие объясняется, на наш взгляд, тем, что быть «нетворческим человеком» в сознании специалистов - не престижно, социально не одобряемо. А вот инновации они не всегда воспринимают позитивно, скорее всего, даже их опасаются, поскольку не до конца понимают их значение в своей деятельности.

Представленные результаты характерны для большинства опрошенных нами инженеров-конструкторов. Однако несколько иную позицию в этом вопросе заняли инженеры-конструкторы Ханты-Мансийского автономного округа (Югры). На вопрос «Нужны ли инновации в вашей деятельности?» утвердительно ответили 35,6\%, «скорее нужны, чем нет» ответили 36,2\%, «скорее нет, чем да» - 19,5\% , «нет» - 6,9\% и затруднились в выборе ответа 1,8\%. По сравнению с инженерами-конструкторами других регионов, инженеры ХМАО (Югры), которые были представлены в нашем исследовании инженерами-конструкторами крупного предприятия ОАО «Сургутнефтегаз», демонстрируют большую готовность к инновациям. На вопрос «Что, по Вашему мнению, в большей степени влияет на качество выполняемой работы?» инженеры-конструкторы этого предприятия, в отличие от других, отвели большую роль исследовательскому творческому потенциалу. Возможно, это объясняется большими финансовыми возможностями данного предприятия, по сравнению с другими, более совершенной системой мотивации специалистов, побуждающих их к более эффективной профессиональной дея- тельности, не возможной в современных условиях без креативности и стремления использовать инновационные методы работы.

По результатам исследования, можно выявить тенденцию к преобладанию установок на инновации и творчество в зависимости от увеличения возраста и стажа, но затем их уровень начинает снижаться. Так, после 45 лет начинается спад уровня инновационной направленности инженеровконструкторов.

Выявлено, что у инженеров-конструкторов в возрасте до 35 лет наблюдается более позитивное отношение к творчеству и инновациям, чем после 45 лет. Также у инженеров-конструкторов ОАО «Сургутнефтегаз» в большей степени выражена установка на инновации, чем у инженеровконструкторов других исследуемых предприятий. Однако она обусловлена не столько самой принадлежностью к профессии, сколько профессиональной средой. Так, наиболее показательной является представленность явной доминации активного инновационного типа установки у специалистов, работающих в условиях инновационной профессиональной ментальности по сравнению с тенденцией преобладания пассивно-положительного типа установки специалистов, работающих в условиях традиционной профессиональной ментальности.

В общем, инженеры-конструкторы исследуемых предприятий осознают необходимость изменений, однако по-разному воспринимают их сущность, а также принципы и методы их осуществления.

Исследования показали, что у большинства инженеров-конструкторов отсутствуют установки на инновации. Судя по ответам, они демонстрируют слабую готовность к инновациям, исследованиям и творчеству в своей деятельности, имеют смутное представление о содержании инновационных процессов и сущности инновационной деятельности, одновременно демонстрируя позитивное отношение к возможности творчества в работе. Данное противоречие также можно объяснить и тем, что техническое творчество составляет основу инженерной деятельности, а особенно деятельности инженеров-конструкторов.

Таким образом, можно сделать вывод, что к внедрению инноваций в свою профессиональную деятельность готова незначительная часть инженеров-конструкторов, что говорит об отсутствии установок на инновации, исследования и творчество в 


\section{Профессиональная психология}

профессиональном сознании инженеров-конструкторов. Это, в свою очередь, свидетельствует о рассогласованном влиянии социально-психологических аспектов, включающих ценностные ориентации и профессиональные установки, имеющихся в реальной профессиональной культуре инженеров-конструкторов. Это оказывает негативное влияние на процесс появления нового системного качества профессиональной культуры, провоцирует ее деформацию и несоответствие решаемым задачам в условиях инновационной трансформации промышленных предприятий.
Выявленная проблема рассогласования ценностных ориентаций и установок, отсутствие связей между ними, свидетельствует о необходимости трансформации профессиональной среды в соответствии с инновационными изменениями и создания новых условий формирования профессиональной культуры, способствующих осознанию инженерамиконструкторами необходимости поиска инновационных подходов к решению своих профессиональных задач, а также позволяющих в полной мере удовлетворить потребности в формировании недостающих элементов своей профессиональной культуры.

\section{Список литературы:}

1. Багдасарьян Н.Г. Профессиональная культура инженера: механизмы освоения. М.: Изд-во МГТУ им. Н.Э. Баумана, 1998. 150 с.

2. Калекина А.В., Калекин В.В. Профессиональная культура инженеров-конструкторов. Омск: ОИВТ (филиал) ФБОУ ВПО НГАВТ, 2012. 85 с.

3. Климов Е.А. Психология профессионального самоопределения. Ростов н/Д: Феникс, 1996.512 с.

4. Никифоров Г.С. Самоконтроль человека. Л.: Наука, 1989. 150 с.

5. Платонов К.К. Структура и развитие личности. М.: Наука, 1986. 370 с.

6. Шадриков В.Д. Деятельность и способности. М.: Издат. корпорация «Логос», 2004. 320 с.

7. Ядов В.А., Кисель А.А. Удовлетворенность работой: анализ эмпирических обобщений и попытка их теоретического обоснования // Социологические исследования. 1974. №1. С. 78-87.

\section{References (transliteration):}

1. Bagdasar'yan N.G. Professional'naya kul'tura inzhenera: mekhanizmy osvoeniya. M.: Izd-vo MGTU im. N.E. Baumana, 1998. $150 \mathrm{~s}$.

2. Kalekina A.V., Kalekin V.V. Professional'naya kul'tura inzhenerov-konstruktorov. Omsk: OIVT (filial) FBOU VPO NGAVT, 2012.85 s.

3. Klimov E.A. Psikhologiya professional'nogo samoopredeleniya. Rostov n/D: Feniks, 1996. 512 s.

4. Nikiforov G.S. Samokontrol' cheloveka. L.: Nauka, 1989. 150 s.

5. Platonov K.K. Struktura i razvitie lichnosti. M.: Nauka, 1986. 370 s.

6. Shadrikov V.D. Deyatel'nost' i sposobnosti. M.: Izdat. korporatsiya «Logos», 2004. $320 \mathrm{~s}$.

7. Yadov V.A., Kisel' A.A. Udovletvorennost' rabotoi: analiz empiricheskikh obobshchenii i popytka ikh teoreticheskogo obosnovaniya // Sotsiologicheskie issledovaniya. 1974. № 1. S. 78-87. 